\title{
Hernando de Mendoça (1562-1617), General Acquaviva, and the Controversy over Confession, Counsel, and Obedience
}

\author{
Nicole Reinhardt \\ Durham University, u K \\ nicole.reinhardt@durham.ac.uk
}

\begin{abstract}
This article examines the clash between Superior General Claudio Acquaviva and the Spanish Jesuit Hernando de Mendoça, briefly confessor to the viceroy of Naples count of Lemos (1599-1601). It argues that Mendoça's activities in Naples and the scandal that followed were an important influence on Acquaviva's determination to formalize and push forward the regulations for princely confessors in 1602. It situates the confrontation within the context of the discontent amongst Spanish Jesuits, and their criticism of Acquaviva's generalate. While Jesuit historiography has generally considered Mendoça's case as an example of individual folly and disobedience, the essay elucidates the significance of his agency by taking into account his overlooked writings, which offer new insights into the controversy over the role of confession for just government within and without the Society of Jesus.
\end{abstract}

\section{Keywords}

Tres tratados - Naples - count of Lemos - Hernando de Mendoça - Claudio Acquaviva princely confessor - distributive justice - venality - obedience

Soon after its foundation, the Society of Jesus received requests from European rulers to supply them with confessors. Although Ignatius of Loyola (c. 1491-1556) decided to provide these spiritual advisers, this decision caused 
anxiety and perplexity amongst his companions. ${ }^{1}$ As years went by, these concerns deepened, and by the late sixteenth century the order was divided over the merits of continuing the policy. ${ }^{2}$ In good Jesuit fashion, these anxieties led to the establishment of a set of decrees. After the fifth general congregation of 1593/94 had warned that princely confessors must not meddle "with public affairs" or "reason of state" and should avoid "seeking familiarity with princes," 3 in 1602 General Claudio Acquaviva (1543-1615) started drafting more specific rules. The idea that confessors should focus on their pastoral mission and eschew secular business remained the backbone of the final instruction for princely confessors, eventually ratified at the sixth general congregation in 1608. Thanks to Robert Bireley's research, we are well informed on the stages in the establishment of the rules De confessariis principum, as well as on the severe limitations regarding their application when put to the test during the Thirty Years' War. ${ }^{4}$

This essay focuses on an affair that might have been a decisive but hitherto overlooked influence on Acquaviva's determination in 1602 to define the rules for princely confessors more precisely. Amidst the drafts for these rules are papers on an inquest into the "scandalous" Spanish Jesuit Hernando de Mendoça (1562-1617), briefly confessor to the viceroy of Naples, Don Fernando Ruiz de Castro Andrade y Portugal, sixth count of Lemos (1548-1601). The location of these inquest papers next to the draft rules suggests a chronological and thematic interconnection between them. ${ }^{5}$ Not only did Mendoça's spell in Naples

1 Monumenta Ignatiana: Series prima; Sancti Ignatii de Loyola epistolae et instructiones (Madrid: López del Horno, 1906), 4:625-28: Ignatius to Diogo Mirão, February 1, 1553. On the first requests for Jesuit confessors, see João Francisco Marques, "Confesseurs des princes, les jésuites à la Cour de Portugal," in Les jésuites à l'âge baroque (1540-1640), ed. Luce Giard and Louis de Vaucelles (Grenoble: Jérôme Millon, 1996), 213-28.

2 See Markus Friedrich, "Politikberatung durch Intellektuelle? Das Verhältnis des Jesuitenordens zu den frühneuzeitlichen Fürstenhöfen im Spiegel von Giulio Negronis Traktat 'Aulicismus, sive de fuga aulae dissertatio,"' in Intellektuelle in der Frühen Neuzeit, ed. Luise Schorn-Schütte (Berlin: Akademie Verlag, 2010), 175-209; Sabina Pavone, Le astuzie dei gesuiti: Le false istruzioni segrete della Compagnia di Gesù e la polemica antigesuita nei secoli XVII e XVIII (Rome: Salerno editrice, 2000), 271-88.

3 Institutum Societatis Iesu (Florence: Typographia ss. Conceptione, 1893), 2:275-76 (decr. 47 and decr. 48); 2:288 (decr. 79).

4 See Robert Bireley, "Hofbeichtväter und Politik im 17. Jahrhundert," in Ignatianisch: Eigenart und Methode der Gesellschaft Jesu, ed. Michael Sievernich and Günter Switek (Freiburg: Herder, 1990), 386-403, here 386-89; Bireley, The Jesuits and the Thirty Years War: Kings, Courts and Confessors (Cambridge: Cambridge University Press, 2003).

5 Archivum Romanum Societatis Iesu [hereafter ARSI ], Inst. 117-II, ff. $487^{\mathrm{r}}-488^{\mathrm{v}}$ : "Instruttione per il Padre Francisco Vipera andando in Napoli intorno alle cose del P. Hernando de Men-

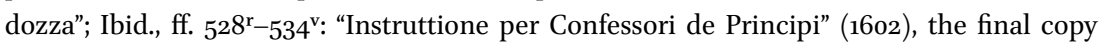


(1599-1602) coincide with the period during which Acquaviva was completing the new guidelines, it also raised issues that were directly relevant to some of the problems these attempted to solve. Moreover, when Mendoça returned to Spain in 1603 as confessor to the viceroy's widow Doña Catalina de Sandoval (1555-1628), the affair took a threatening turn that subverted the superior general's most fundamental attribute, namely his capacity to elicit and impose obedience. ${ }^{6}$ The evidence of the Mendoça affair suggests that Acquaviva's disciplining of princely confessors was concerned not merely to protect the order against exterior criticism but also to limit these confessors' potentially disruptive effect on the Society's interior hierarchy and cohesion.

The general's struggle with Mendoça had considerable local, international, political, and religious ramifications. It is best understood in the context of the deep crisis that agitated the order at the turn of the sixteenth century, after a "Spanish revolt" had developed after the death of the last Spanish general, Francisco de Borja (1510-72; in office, $\left.15^{6} 5^{-72}\right) .{ }^{7}$ As is well-known, the conflict took more dramatic forms under Acquaviva and peaked around the general congregations of 1593 and 1608 , which frame the Mendoça affair chronologically. The discontent amongst Spanish Jesuits offered the Spanish crown as well as the papacy long-sought opportunities to challenge the authority of the Jesuit general from different angles, and for different motives. In Spain, the Jesuits' privileges and their distinctive Constitutions conflicted with the Inquisition as well as with the crown's aspiration to control the national clergy. In Rome, questions of doctrine, but also papal authority and influence over the general were at issue. Although some scholars have alluded to Mendoça's role in these events, the nature of his involvement is little understood. ${ }^{8}$ Jesuit historians in

signed by Acquaviva on February 10, 1602 on $\mathrm{ff} .540^{\mathrm{r}}-541^{\mathrm{v}}$. Vipera's mission to Naples was in January 16o2: ARSI, Neap. 6-II, ff. $470^{\mathrm{v}}-42^{\mathrm{v}}$ : Acquaviva to Padre Fabio, provincial of Naples, January 26,1602 .

6 A confused and Manichean account of Mendoça's return to Spain, oblivious to the Neapolitan link is in José Martínez Millán, "La doble lealtad en la corte de Felipe III: El enfrentamiento entre los padres R. Haller S.I. y F. de Mendoça S.I.," Librosdelacorte.es 1 (2014): 136-62.

7 On Mercurian's election, the following anti-converso policies and the exodus of leading Spanish Jesuits, see Robert A. Maryks, "The Jesuit Order as a 'Synagogue of Jews': Discrimination Against Jesuits of Jewish Ancestry in the Early Society of Jesus," Archivum historicum Societatis Iesu 156 (2009): 339-416. For the eruption of dissent under Acquaviva, see Michela Catto, La Compagnia divisa: Il dissenso nell'ordine gesuitico tra '50o e '6oo (Brescia: Morcelliana, 2009), Ch. 3; on Acquaviva's re-orientation and centralization of the order, see Paolo Broggio et al., eds., I gesuiti ai tempi di Claudio Acquaviva: Strategie politiche, religiose e culturali tra Cinque e Seicento (Brescia: Morcelliana, 2007), Introduction.

8 See Ricardo García Cárcel, "La crisis de la Compañía de Jesús en los últimos años del reinado de Felipe II (1585-1598)," in La monarquía de Felipe II a debate, ed. Luis Ribot (Madrid: Sociedad estatal para conmemoración de los centenarios de Felipe II y Carlos V, 2000), 383-404; 
particular, whilst never mincing their words to condemn Mendoça's disobedience, have paid remarkably little attention to his ideas. ${ }^{9}$ The Jesuit historian Antonio Astrain, for instance, never mentions that the "rebel" Mendoça was also the author of two remarkable and widely noticed publications, which might be relevant to his agency: one on the faults of the Jesuit Constitutions, ${ }^{10}$ the second, under the title Tres tratados, ${ }^{11}$ on problems of distributive justice. On the other hand, the few scholars who have shown an interest in Mendoça's writings generally neglect the institutional and biographical context in which they emerged. ${ }^{12}$

The disconnection between studies of Mendoça's writings and studies of his activities is no accident. It reflects the skewered arrangement of the relevant

José Martínez Millán, “Transformación y crisis de la Compañía de Jesús (1578-1594)," in I religiosi a corte: Teologia, politica e diplomazia in antico regime, ed. Flavio Rurale (Rome: Bulzoni, 1998), 101-29; see also Maria Antonietta Visceglia, Roma papale e Spagna: Diplomatici, nobilie religiosi tra due corti (Rome: Bulzoni, 2010), 191-206; still useful, though biased is Antonio Astrain, Historia de la Compañía de Jesús en la asistencia de España, vol. 3: Mercurian-Acquaviva, 1573-1615 (Madrid: Razón y fe, 1909), Ch. x and xx. There is no mention of Mendoça in Catto's study on Jesuit dissenters. For an account on the complex tensions between Madrid and Rome, see Paolo Broggio, "Rome and the 'Spanish Theology': Spanish Monarchy, Doctrinal Controversies and the Defence of Papal Prerogative During the Pontificate of Clement VIII," in The Spanish Presence in Sixteenth-Century Italy: Images of Iberia, ed. Peter Baker-Bates and Miles Pattenden (Farnham: Ashgate, 2015), 98-102.

9 "Paranoia" is quoted by Enrique G. Fernández in his entry on Mendoça in Diccionario histórico de la Compañía de Jesús, ed. Charles O’Neill and Joaquín M. Domínguez (Rome-Madrid: IHSI-Universidad Pontificia Comillas, 2001), 3:2624.

10 Published in French under the title Advis de ce qu'il y a à réformer en la Cõpagnie des Iesuites, presenté au pape \& à la congregation generale, par le Père Hernãdo de Mendoça du mesme ordre. Ensemble plusieurs Lettres des Indes Orientales, escrites par des Peres Iesuittes, \& autres de l'Ordre de S. François, traduictes du Portugais (s.l., s.p., 1615); the circumstances of the publication are obscure.

11 Tres tratados compuestos por el P. Hernando de Mendoça de la Compañia de Iesus para el Ilusstrissimo y Excellentissimo Señor Conde de Lemos Virrey de Napoles y mandados imprimir por el Señor Don Francisco de Castro su hijo, y successor en el mismo cargo. El primer de las Gracias; el segundo de los Officios vendibles; el tercer de las Tratas (Naples: Tarquinio Longo, 1602).

12 Guenter Lewy, "The Struggle for Constitutional Government in the Early Years of the Society of Jesus," Church History 29, no. 2 (1960): 141-6o, focuses exclusively on the Advis. The Tres tratados have been mentioned by social historians, but not understood within the theological or Jesuit framework; see Roberto Mantelli, Il pubblico impiego nell'economia del Regno di Napoli: Retribuzioni, reclutamento e ricambio sociale nell'epoca spagnuola (secc. XVI-XVII) (Naples: Istituto italiano per gli studi filosofici, 1986), 107-36, 255-94. 
records in the Jesuit archives in Rome, where his disobedience was established post factum and in purely behavioral terms between 1606 and $1608 .{ }^{13}$ Although the absence of an official reaction to Mendoça's writings by the Jesuit hierarchy is not necessarily surprising, the silence within the order's remaining internal documentation is remarkable, and it renders the disentangling of Mendoça's case particularly complex. ${ }^{14}$ The passionate criticism in almost all surviving statements is largely explained by Mendoça's erratic and idiosyncratic behavior, but there is also evidence that the nature of these criticisms induced Acquaviva to exclude crucial communications relating to the affair deliberately from the records. Moreover, a set of letters by Mendoça disappeared during the course of the conflict, when pope Clement VIII (1536-1605; r.1592-1605) ordered the general to hand them over to him. ${ }^{15}$

This article tries to re-establish the link between Mendoça's disobedience and his ideas offering a fuller explanation of the episode and its protagonists. Importantly, by showing how this politically contingent episode triggered an explosive controversy over the nature of just government and the role of confession herein, it clarifies how and why pastoral and Jesuit constitutional discussions overlapped. The reconstruction of the episode and its ramifications therefore elucidates the crucial role of the instructions for princely confessors for Acquaviva's widely recognized top-down hierarchical reorganization of the Society.

13 An account of Mendoça's wrong-doings was established in 1606 by the secretary of the order Bernardo de Angelis for the provincial of Naples: ARsI, Neap. Epist. 194-I, ff. $39^{\mathrm{r}}-48^{\mathrm{r}}$, forming the basis for an inquest to be conducted in Spain in 16o6-8, ARsi, Cast. 33, ff. $12^{\mathrm{v}}-136^{\mathrm{r}}$ : "Interrogatorio contra M., 1606-16o8." The contemporary wider inquest Detrimenta Societatis also focused on discipline, see Catto, Compagnia divisa, 113 .

14 After 1600 incoming letters were no longer systematically conserved, and under Muzio Vitelleschi material in relation to the conflicts surrounding General Acquaviva was deliberately destroyed, see Flavio Rurale, "Lo sguardo o la mano del generale': Problemi e prospettive di ricerca nell'Archivum Romanum Societatis Iesu," in Gli archivi per la storia degli ordini religiosi, I: Fonti e problemi (secoli XVI-XIX), ed. Massimo Carlo Giannini and Matteo Sanfilippo (Viterbo: Sette Città, 2007), 93-109, here 97-99.

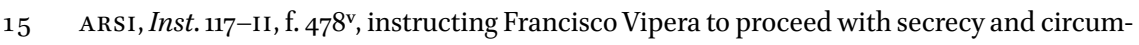

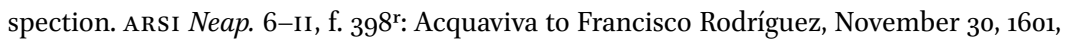
requesting an oral report in Rome. Following a request by the countess of Lemos, Clement viII ordered Acquaviva to hand over all letters he had received from Mendoça, see Astrain, Historia de la Compañía de Jesús, 3:637; this seems to have affected all the letters received in 1602 . 


\section{Questions of (Dis-)obedience}

When Mendoça arrived in Naples in 1599 his name rang a bell in the Jesuit headquarters in Rome. The Spaniard had acquired a reputation for nonconformist behavior, including association with the malcontent memorialistas, which had prompted frequent moves from one college to another. ${ }^{16}$ According to the report into his misdoings established in 1606 , he had breached the Jesuit Constitutions on a regular basis: gambling, luxurious Dutch shirts, a distinct love for mundane company, "liberty," and contempt for his superiors loomed large in this list. ${ }^{17} \mathrm{He}$ was also said to have sought dismissal from the Society of Jesus around 1591, a request which Acquaviva allegedly refused. ${ }^{18}$ As the Jesuit historian Francesco Schinosi (1650-1723) remarked, Mendoça had been too clever for his own good, which was why Acquaviva decided in 1597 to relegate him to Monforte in Galicia, so that "far away from often pernicious and specious friends he might dispose of his many talents in a more beneficial manner before old age made them rusty."19

The general had been too optimistic. Once he arrived in Monforte, Mendoça struck a bond of friendship with the count and countess of Lemos, the protectors of the local Jesuit college. The couple not only took him on hunting parties, but recruited him as their confessor. This opened exciting perspectives: the patronage leverage of the countess of Lemos, sister to the royal valido Lerma (1552-1625) and a hugely influential broker of the Sandoval clan, was extraordinary. ${ }^{20}$ In 1599 , when her husband was appointed viceroy of Naples,

16 He had taught at the colleges in Segovia and Ávila, studied theology in Salamanca, then moved from the college in León into that of Medina de Campo, before his "banishment" to Monforte. The investigation conducted in 1606 suggested that in each location there were reports on his eccentricity and disobedience: ARsI, Cast. 33, f. $133^{\mathrm{r}}$.

17 The Jesuit Constitutions regarded luxurious clothing and contempt for superiors as coterminous signs of disobedience, see The Constitutions of the Society of Jesus, trans. George E. Ganss (St. Louis, MO: Institute of Jesuit Sources, 1970), 245-58.

18 ARSI, Neap. Epist. 194-I, f. 39 ${ }^{\mathrm{r}}$. On the reluctance regarding dismissals in general, see Sabina Pavone, "I dimessi della Compagnia negli anni del generalato di Francesco Borgia: Una nuova questione storiografica," in Francisco de Borja y su tiempo: Política, religión y cultura en la Edad Moderna, ed. Enrique García Hernán and Maria del Pilar Ryan (Valencia: Albatros Ediciones, 2011), 465-79.

19 Francesco Schinosi, S.J., Istoria della Compagnia di Giesu, appartenente al Regno di Napoli: Parte seconda (Naples: Luigi Mutio, 1711), 399.

20 See Hillard von Thiessen, "Herrschen mit Verwandten und Klienten: Aufstieg und Fall des Herzog von Lerma, Günstlings-Minister Philipps III. von Spanien," in Nützliche Netzwerke und korrupte Seilschaften, ed. Arne Karsten and Hillard von Thiessen (Göttingen: Vandenhoeck \& Ruprecht, 2006), 181-206. 
they all set sail to Italy without awaiting the consent of Mendoça's superior. ${ }^{21}$ Such nonchalance set the pattern for the following years, and Acquaviva initially seemed content to go along with this: he granted virtually all of Doña Catalina's "requests" to award her confessor with privileges and exemptions from constraining rules, and when Mendoça took his fourth vow, the countess received permission to hold a splendid public celebration. ${ }^{22}$ Contrary to the later allegations suggesting that Mendoça had always led a scandalous life, when Acquaviva in 1599 requested certificates of his good conduct in Spain and Naples, before admitting him to the last vows, no concerns were raised. ${ }^{23}$

The reasons for Acquaviva's generosity towards Mendoça and his patrons can be easily identified: they established a relationship of mutual obligation full of symbolic and political potential. The countess was not only Lerma's sister. The siblings, through their mother, were also the grandchildren of the last Spanish Jesuit general, Francisco de Borja. ${ }^{24}$ Mendoça could now provide access to a family which was at once "Jesuit royalty" and in control of Philip III (1578-1621) and his court. Both were of enormous strategic importance: proximity to the Sandoval-Borja connection could be a means to overcome the sense of alienation and resentment that had animated the Spanish Jesuit "rebels" for decades, whilst Lerma's protection could help to acquire vital royal favor for the entire order. Keeping the Sandovals happy was a bonus however one regarded it. It was especially crucial at this particular moment, when a condemnation of Molinism, with fatal consequences for the order's identity and maybe its very existence seemed likely. ${ }^{25}$

21 See Isabel Enciso Alonso-Muñumer, "Filiación cortesana y muerte a Nápoles: La trayectoria del vi conde de Lemos," in Felipe II y el Mediterráneo, ed. Ernest Belenguer Cebrià (Madrid: Sociedad estatal para la conmemoración de los centenarios de Felipe II y Carlos V, 1998), 3:515-61.

22 ARSI, Neap. 6-I, s.p.: Acquaviva to Ludovico Manzoni, provincial of Naples, July 24, 1599 permission to reside in the novitiate; f. $160^{\mathrm{r}}$ : December 23,1599 on special public festivities to celebrate Mendoça taking his final vows.

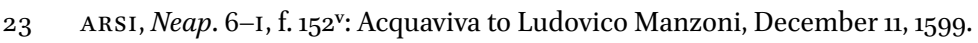

24 See Patrick Williams, "Grandson of St Francisco de Borja: The Duke of Lerma as Patron of the Church," in Francisco de Borja y su tiempo, 371-93; Jodi Bilinkoff, "A Christian and a Gentleman: Sanctity and Masculine Honor in Pedro de Ribadeneyra's Life of Francis Borgia," in Francisco de Borja y su tiempo, 447-55.

25 The Spanish Inquisition had started inquests into the Jesuits before the doctrinal conflict took on wider scope in 1594 with the papal de auxiliis congregation, see Paolo Broggio, La teologia e la politica: Controversie dottrinali, curia romana e monarchia spagnola tra Cinque e Seicento (Florence: Leo Olschki, 2009), 69-118. 
But Acquaviva soon discovered the limits of this deceptively promising arrangement. Signs that it was starting to backfire emerged in the late summer of 1600, when the countess complained that Jesuits in the province of Naples had started "badmouthing" Mendoça. With some anxiety, Acquaviva reminded the Neapolitan Jesuits how vital maintaining the affection of the Lemos was for the Society. ${ }^{26}$ Yet when the viceroy died in October 1601 and his widow stayed on with her second son Don Francisco Ruiz de Castro (1579-1637), who acted as interim-viceroy, serious mud-slinging began. The preposito of Naples reported that according to one of his lady penitents secret plans existed to "elevate Mendoça to a bishopric," and that he had used his position to line his pockets. ${ }^{27}$ Mendoça was accused of acting in a secular fashion, indulging in elegant clothing, silk slippers, and nocturnal outings. As the Jesuit secretary recorded, a few years later:

People were grievously pained by his haughty imperiousness, his interest in and greed for money, and the favor he showed to the undeserving, whilst he burdened others and treated them without courtesy and most illiberally. He conducted himself with some women in a manner unbecoming to a religious. [...] He put people and their offices at risk. [...] People considered him the origin of their woes and behind him the Society that put up with him. ${ }^{28}$

Doña Catalina was furious, and informed Acquaviva as well as her friends and family in Spain, that a cabal of viceregal councillors and local Jesuits spread the most shameless gossip. ${ }^{29}$ The general immediately ordered a special envoy to travel to Rome and inform him in person, ${ }^{30}$ and when some days later, he received a list of the suspected slanderers amongst the Neapolitan fathers,

26 ARSI, Neap. 6-I, f. $240^{\text {r: }}$ : Acquaviva to Carlo Mastrelli, August 19, 160o. This was also the concern with regard to Richard Haller, the confessor of Queen Margarita, who was one of Lerma's fiercest critics. In 1604, Haller was forced to send a long justification to the general explaining that he had not been hostile to the valido, ARSI, Cast. 33 , ff. $109^{\mathrm{r}}-112^{\mathrm{r}}$. This contradicts Martínez Millán's assessment of Haller as a tool of submitting Madrid to Rome, Martínez Millán, “La doble lealtad.”

27 ARSI, Neap. Epist. 194-I, f. 14 ${ }^{\text {r }}$ Lucas Pinelli to Acquaviva, October 22, 1601; the viceroy had died three days earlier.

28 ARsi, Cast. 33, f. 133'; ARsi, Neap. Epist. 194-I, ff. $39^{\mathrm{v}}-40^{\mathrm{r}}$ : Bernardo de Angelis to the provincial of Naples, May 2, 1606 .

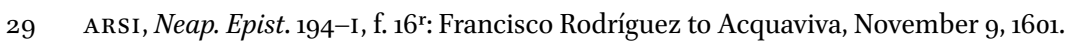

30 ARSI, Neap. 6-II, f. $39^{\text {r }}$ : three separate letters by Acquaviva to the countess of Lemos, Mendoça, and Francisco Rodríguez dated November 10, 1601. 
he ordered them to retract: "For God's sake let's be cautious and not lap up everything that laymen tell us, even when they do so moved by zeal, because dies mali sunt [times are bad], and sometimes the very people who complain are the authors of what they complain about and then make us authors of the fables they tell." ${ }^{31}$

Yet, his attempts to soothe the situation failed, matters turning openly hostile when in January 1602 Acquaviva sent Francesco Vipera (1532-1605), former provincial of Genoa, to Naples with orders to conduct a full investigation. The instructions to Vipera show that although Acquaviva did not believe the allegations that Mendoça had taken kick-backs for favors, he accepted that he had behaved foolishly and like a courtier. ${ }^{32}$ The main problem, however, was the choice of Vipera as investigator. Mendoça and the countess interpreted it as a deliberate provocation and personal offence, since they had clashed with him already in Genoa when on their way to Naples he had objected to Mendoça staying not in the Jesuit house but in the palace with the Lemos couple. ${ }^{33}$

The countess therefore refused to receive Vipera and Mendoça at this point apparently wrote a defiant letter to the general, which Acquaviva was later forced to hand over the pope. Acquaviva's reaction was weary, "paternally" admonishing his "subject" to reflect on the tone he adopted. The general was outraged at the condesa's threat that, if he did not banish the accused fathers immediately, she would withdraw her protection from the order. Acquaviva regarded this as intolerable and reflecting a failure by Mendoça in his pastoral role: the confessor's first duty of obedience was to God and the general, not to his penitent; it was his responsibility to call the countess to order, reminding her that her affection for her confessor must be directed not towards his person, but towards the Society of Jesus as a body. ${ }^{34}$ Yet Mendoça and Doña Catalina made it clear that they considered themselves above the Jesuit chain of obedience. They appealed directly to Clement VIII to grant a brief that not only cleared Mendoça's name, but also prohibited any investigation into his conduct. When the countess returned to Spain to become lady-in-waiting to the Queen, the pope granted Mendoça a host of privileges that allowed him to

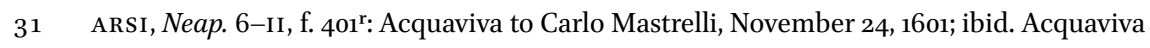
to Luca Spinelli, preposito di Napoli, November 24, 1601.

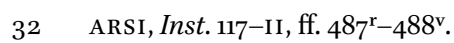

33 ARsi, Neap. 6-II, ff. $470^{\mathrm{v}}-42^{2}$ : Acquaviva to Padre Fabio, provincial of Naples, January 26 , 16o2; ff. $473^{\mathrm{r}}-474^{\mathrm{r}}$ : Acquaviva to Vipera, January $26,1602$.

34 ARSI, Neap. 6-II, ff. $472^{\mathrm{v}}-473^{\mathrm{v}}$ : Acquaviva to Mendoça, January 26, 1602; f. $472^{\mathrm{v}}$ : "dirò confidentemente e paternamente a lei non penso di rispondere parola adesso, perchè è scritta con tal termine, che pare che il scrittore non si ricordasse ne di che, ne a chi scriveva." 
conduct his office as her confessor in whatever way he pleased, without supervision from his superiors. ${ }^{35}$

The confrontation with Mendoça undoubtedly convinced Acquaviva how urgent it was to clarify, reinforce, and implement instructions for princely confessors, and some passages in the draft rules of 1602 are reminiscent of the general's problems during this episode. There was an insistence that the princely confessors must live as

subjects of the ordinary and observe the habitual discretion and rules that apply to all, and there must be no exception, no matter under what pretext, even though the business they might conduct for the Prince requires secrecy [...]. They must observe the Regula, and where there is abuse the Provincial has to impose himself and make sure that rules are observed [...] they must not have, receive or hold any money, distribute or receive presents, because all these things, such as going out without permission and where they like, destroy the order and its spirit in the mind of people and they are in no way necessary to the service of the Prince or beneficial to his office. ${ }^{36}$

The regulations also stressed that the confessor must always work to "direct the Prince's affection and devotion to the Society, not to his own person, because this is a pestilence for him and the order." ${ }^{37}$ The Mendoça affair was in many ways a textbook case of the dangers inherent in supplying princes with confessors: sliding into worldliness was a matter not only of clothing and mingling with courtiers, but also of active involvement in "politics," particularly in the distribution of grace as part of government, through which the entire order attracted criticism of factionalism. Particularly worrying, however, were the repercussions on discipline. If critics of the Society of Jesus feared that Jesuit confessors used the confidence and access they enjoyed to exploit rulers in their order's interest, the example of Mendoça showed another-contrary — reality: that confessors might use their penitents' and patrons' affection for their own ends, to escape the constraints of their position and to defy the general's leadership, undermining the very principles of (Jesuit) obedience. Mendoça had

35 ARsi, Cast. 33, ff. $113^{\mathrm{r}-\mathrm{v}}$.

36 ARSI, Inst. 117-II, f. $5^{28^{r}}$. On the increased focus on obedience see also John W. O'Malley, The First Jesuits (Cambridge, MA: Harvard University Press, 1993), 338-45, 368-97; Silvia Mostaccio, Early Modern Jesuits between Obedience and Conscience during the Generalate of Claudio Acquaviva (1581-1615) (Farnham: Ashgate, 2014), 55-81. 
even managed to mobilize papal authority to resist the general, giving a singular and unintended meaning to the Jesuit submission to the pontiff.

\section{Tyranny and Confession}

Mendoça's disobedience did not cease with his return to Spain. Using the royal court as his stage, he now pressed matters onto an ideological level, whipping up the still numerous Jesuit malcontents in Spain against the general. ${ }^{38}$ Despite the clamp-down on the Spanish perturbatores after the fifth general congregation in 1593 , the Castilian province in particular continued to be riddled with strife, and the flow of memoranda denouncing the general's "tyranny," disorderly management, and disregard for the Spanish element within the Society, would not cease. Mendoça, sniping against Acquaviva, Robert Bellarmine (1542-1621) and the queen's confessor, the Austrian Jesuit Richard Haller (15511612), now became their spokesman. Crucially, with the help of his penitent, he mobilized both papal and royal support against Acquaviva and to demand that he should visit the Spanish provinces in order to acknowledge and recognize their woes. ${ }^{39}$ Eventually, only Clement VIII's death in March 1605 prevented this humiliation and, as the Jesuit historian Astrain famously put it, "for the second time God saved the Society from grave peril by the death of His vicar."40

Probably around this time, Mendoça composed a memorandum, "leaked" years later (1615) in French translation, which severely criticized the Jesuit Constitutions. ${ }^{41}$ The Advis de ce qu'il y a à réformer dans la Compagnie

38 Astrain describes the associated cabals in great detail, see Historia de la Compañía de Jesús, 3:640-55.

39 ARsi, Cast. 33, f. 134 ${ }^{\mathrm{r}}$; ARsI, Neap. Epist. 194-I, f. $44^{\mathrm{v}}$ : Bernardo de Angelis to the provincial of Naples, May 2, 1606. This is also confirmed by Juan de Mariana's critical memorandum, which alludes to Mendoça's case as a consequence and symptom of the defects of the order's Constitutions, but which remains critical of Mendoça, see Discours du Père Iean Mariana, Iesuite Espagnol des grands defauts qui sont en la forme du gouvernement des Iesuites: Traduict de l'Espagnol (s.l., s.p.: 1625), 48. Mariana had probably worked on his Discurso since the 1590s, see Catto, Compagnia divisa, 162, but this passage points to an update around 1605 .

40 Astrain, Historia de la Compañía de Jesús, 3:651. The first danger had occurred only a few years earlier under Sixtus v.

41 It is possible that Mendoça had written it already in the 1590s, when other critical memoranda mushroomed, see Astrain, Historia de la Compañía de Jesús, 3:410-420. Lewy, "The Struggle for Constitutional Government," 150 suggests that it dated from 1605 after his return to Spain, Pavone situates it at the eve of the sixth general congregation in 1606 , 
revolved around two core points: the general's "absolutism" and the (ab)use of confession as a tool of government within the Society. Mendoça reiterated a demand rejected at the fifth general congregation that the general's term of office should be limited to six years. He explained the reasons for this in highly politicized terms: "As they [the generals] are appointed perpetually and never held to account, they become insolent absolute tyrants [sic] who commit many injustices, and they cannot be stopped, as one can see in this Society." ${ }^{2}$ The institutional defect was exacerbated by incomplete and unfair gathering of information. According to Mendoça, the reliance on the Jesuit system of long-distance reporting and filing, instead of first-hand inspection, profoundly distorted the order's government. ${ }^{43}$ It produced a closed and dysfunctional system that fomented slander and back-stabbing at the bottom and biased information at the top, which in turn resulted in bad counsel and unjust, "tyrannical" government. ${ }^{44}$ To redress this problem, Mendoça suggested that the general should personally visit each province at least every six years and that the Spanish provinces should elect a special general, residing in Spain, to protect and oversee their interests. ${ }^{45}$ This demand echoed a wider call for decentralization and greater autonomy for the provinces that was shared by most Spanish malcontents, one of which, Juan de Mariana (1536-1624), formulated his own criticism of the Jesuit Constitutions during the same period. ${ }^{46}$ The critics, then, established a direct connection between flawed information gathering on the one side and the negative features of centralization on the other.

see Sabina Pavone, "Between History and Myth: The Monita secreta Societatis Iesu," in The Jesuits II: Cultures, Sciences, and the Arts, 1540-1773, ed. John O'Malley et al. (Toronto: University of Toronto Press, 2006), 50-65, here 56. Curiously, the inquest into Mendoça's behavior of 1606 whilst mentioning his involvement with other "perturbatores" makes no reference to the memorandum, ARSI, Cast. 33 , f. $133^{\mathrm{r}}$.

42 Mendoça, Advis, 3. See also Harro Höpfl, Jesuit Political Thought: The Society of Jesus and the State, c. 1540-1630 (Cambridge: Cambridge University Press, 2004), Ch. 2 and 10.

On the Jesuit communication network, see Markus Friedrich, Der lange Arm Roms?: Globale Verwaltung und Kommunikation im Jesuitenorden, 1540-1773 (Frankfurt a. M.: Campus Verlag, 2011).

Similarly, Mariana, Discours, 104: "Rome est esloignée, le Père General ne cognoist les personnes, ny les actions, au moins en toutes leurs circonstances, principal fondement des iugemens." Mendoça, Advis, 3-4.

46 Mariana, Discours, 159-168. See also Marie-Lucie Copete, "Le 'discurso de las cosas de la Compañía (1605)' de Juan de Mariana," in Les antijésuites: Discours, figures et lieux de l'antijésuitisme à l'époque moderne, ed. Pierre-Antoine Fabre and Catherine Maire (Rennes: Presses universitaires de Rennes, 2010), 165-78; Lewy, "The Struggle for Constitutional Government," 150-57; Höpfl, Jesuit Political Thought, 244. 
A crucial aspect herein - which Mariana, however, left unmentioned - was the use of confession as an instrument of Jesuit government. The question was a particularly sensitive one, which the Jesuits' external critics and enemies like the Dominicans also tended to emphasize, suggesting in particular the Jesuits' regular infringements on the secrecy of confession. ${ }^{47}$ The Advis fuelled such accusations as it stressed the particularly damaging allegation that Jesuit regulations undermined the charitable precept of fraternal correction.

The problem of "fraternal correction" was hotly debated in sixteenth-century Spain, exposing tensions and contradictions between the authority of confessors and inquisitors. ${ }^{48}$ The precept based on Matthew 18:15 was widely used in canon law and commonly applied in the governance of religious orders. Mendoça's complaints focused on his order's often ambiguous handling of the sacrament of penance amongst its members. The regulations prescribed not only that every Jesuit unveiled his conscience to his superior every six months outside confession, but also, and crucially, that during this process they must reveal the failings of their confrères. Once a year, they had to "manifest their consciences" to their superior, "in confession, or in secret," so that he could direct them "along the path of salvation." ${ }^{49}$ In addition, all Jesuits had to confess regularly to an appointed confessor of their professed houses who should not be the superior. However, in reserved cases only the superior could pronounce absolution, so he still gathered sensitive and confidential information on the men he ruled. This was highly problematic: obviously, superiors could not use information gathered in confession, but the boundaries between confession and administrative disciplining powers were blurred. It seemed unlikely that a superior would not put to use the knowledge he held via the "confessional," particularly as the fifth general congregation had included "sedition" and "disobedience" in the reserved cases. As Mendoça's experience demonstrated, this was a flexible category that could include anything from wardrobe extravagance to articulate institutional criticism. ${ }^{50}$ According to Mendoça, the system not only enabled superiors to identify and eliminate critical voices while formally preserving confessional secrecy, but also provided an open invitation

47 Mendoça, Advis, 13-16; for the wider picture, see Catto, Compagnia divisa, 130-34; Mariana despite his otherwise critical view on the Jesuit government had written an unpublished defence of the Jesuit use of confession.

48 See Vincenzo Lavenia, "Assolvere o infamare: Eresia occulta, correzione fraterna e segreto sacramentale," Storica 20/21 (2001): 89-154; Stefania Pastore, "Correzione fraterna," in Dizionario storico dell'Inquisizione, ed. Adriano Prosperi, John Tedeschi, and Vincenzo Lavenia (Pisa: Edizioni della Normale, 2010), 2:415-18.

49 Constitutions of the Society of Jesus, Part VI, 250.

5o Institutum Societatis Iesu, 2:277-78 (decr. 51). 
to the evil-minded to denounce their fellows or spread unfounded allegations. Hence many Jesuits, he claimed, tried to avoid confession altogether with obvious deleterious consequences for their and the order's spiritual health. ${ }^{51}$ Against this, Mendoça vehemently defended what he considered to be an imprescriptible right to fraternal correction to protect all Christians against damage to their most precious property, i.e. their fama and reputation, i.e. the essence of their honor. ${ }^{52}$ It could not be abolished by entering a religious order, and, as he stressed, nobody was asked formally to renounce to it upon entering the Society of Jesus. Jesuit practice therefore annihilated a core element of charity and justice, supporting the existing structural drift towards arbitrary and potentially tyrannical government.

These allegations were not entirely new or original, but with Mendoça's arrival in Madrid they re-gained traction, giving credence to the anti-Jesuit myths that members of the Society as a matter of principle leaked and used information gained in confession. ${ }^{53}$ It is probably no coincidence that with Mendoça's return to Spain, Pedro de Ribadeneyra (1526-1611) felt prompted to react authoritatively to such criticism. In 1605 , he published a large volume in defence of the Society and its Constitutions, on which he had been working for some time. Using an arsenal of theological authorities, his defensive Tratado sought to demonstrate that the Jesuit regulations were neither extravagant nor contrary to Catholic doctrine. ${ }^{54} \mathrm{He}$ insisted that many of the traits under attack were common to a wide range of rules of the regular clergy, such as the Dominicans, and also defended the order's specific rules in terms of its particular missions and goals. Ribadeneyra emphasized that the critics had not

$5^{1}$ Mendoça, Advis, 14. This was a real problem, see Patrick O'Banion, “'A Priest that appears good': Manuals of Confession and the Construction of Clerical Identity in Early Modern Spain," Dutch Review of Church History 85 (2005): 333-48, here 333-34.

52 Mendoça, Advis, 15: "Que la correction s'observe comme est couchée en l'Evãgile, \& exposée par les saincts Docteurs, \& soit osté cet article de la règle de la Compagnie, qui dit, Que chacun soit content que les fautes \& erreurs qui auront esté remarquees en luy, soient manifestees par qui que ce soit qui les sçache hors la Confession: afin que delà on n'infere pas, que l'on puisse avoir recours aux Superieurs avec le peché mortel secret, en disant que par cet article on a renoncé au droict \& obligation de la correction fraternelle." Lewy is therefore wrong to believe that Mendoça wanted to abolish fraternal correction.

See Pavone, Astuzie dei gesuiti, 167-77. In this context, Richard Haller also defended his order against such accusations: Biblioteca Bartolomeu March (Palma de Mallorca), Papeles Aliaga, vol. II, ff. 292 $2^{\mathrm{r}-\mathrm{v}}$ : Richard Haller to Lerma (?), June 13, 1609.

54 The volume was largely completed by 1602 and explicitly aimed at the critics within the order, see Catto, Compagnia divisa, 149-57. Ribadeneyra quoted many Dominican authors to demonstrate his points. 
understood that on entering a religious order, one submitted to a higher end; it was necessary therefore, to privilege "the benefit of the brother's soul over his fama and reputation." ${ }^{55}$ Ribadeneyra did not dignify the critics by giving their names, and he caricatured them as "a handful of young people, friends of liberty, enemies of rigor and religious observance, moved by self-interest." ${ }^{56}$

\section{Distributive Justice and Good Counsel}

Although official Jesuit records tend to regard Mendoça's lack of obedience, of which his lax conduct was just one symptom, as the reason for the scandal he caused in Naples, another text by Mendoça suggests an alternative explanation for why the report on him in 1606 remarked that he had angered the good society of Naples by showing favor "to the undeserving, whilst he burdened others and treated them without courtesy and most illiberally" 57 What might have been at issue was how he counselled the viceroy in matters of conscience. In 1602, shortly after Lemos's death, Mendoça published three small treatises on the principles he had followed in his office that appeared together under the title Tres tratados. They were a scathing indictment of venality and other abuses in the vice-kingdom, which have earned Mendoça the reputation of a "moral rigorist" (!) among social historians of Naples. ${ }^{58}$ The Tres tratados are indeed a perfectly serious piece of moral reasoning on the problem of acceptio personarum [so-called "respect of person"], the major sin against distributive justice, another controversial topic among Spanish moral theologians at that time. ${ }^{59}$ It revolved around the question of how far personal preference might influence the distribution of offices and royal grace, and whether venality was a cause of injustice because it prevented the appointment of the most

55 Pedro de Ribadeneyra, Tratado en el qual se da razon del Instituto de la religion de la Compañia de Iesus (Madrid: Colegio de la Compañía de Jesús de Madrid, 1605), 300-1.

56 Ribadeneyra, Tratado, 295. Other passages too seem a direct reply to Mendoça and his followers: cap. XXIX (on the designation of superiors by the general), cap. XxxI (on the election of the general for life), cap. XXXII (on revealing one's conscience to the superior), cap. XXXIII (on confession with the superior), cap. XXXIIII (on fraternal correction).

57 ARSI, Neap. Epist. 194-I, f. $39^{\mathrm{v}}$.

58 See Mantelli, Pubblico impiego, 109, and 107-36, 255-94 for a thorough socio-economic analysis of the practices Mendoça denounced.

59 The debate intensified at the beginning of the reign of Philip III, when there were high hopes for an overhaul of royal administration, see Patrick Williams, "Philip III and the Restoration of Spanish Government, 1598-1603," English Historical Review 88, no. 4 (1973): $75^{-69}$. 
qualified people, damaging the res publica and the common good. ${ }^{60}$ While the controversy was generally fought out in Latin folios authored by some of the major voices of Iberian second Scholasticism, Mendoça published his argument in Spanish, adding supporting expert statements in Latin by a handful of serious theologians from the kingdom of Naples. As he explained in his introduction, his tract was just the beginning, and he was prepared to follow up the details during confession, a remark that suggests that the treatise had already been under preparation during the viceroy's lifetime. ${ }^{61}$ Mendoça insisted that he was obliged to tackle this problem publicly, given the eye-watering levels of scandalous favoritism and venality in the administration of the vice-kingdom. He was forced to do so because the Neapolitan clergy out of ignorance or sinful lack of moral principles were an obstacle to moral and political reform. They had even accused him of being "scrupulous," no compliment given that moral theologians generally likened "scrupulosity" to a kind of moral hypochondria. ${ }^{62}$ The Tratados not only showcased how acceptio and venality had to be analyzed from the viewpoint of moral theology but also that Mendoça possessed the expert knowledge and moral competence to perform the office of confessor and counsellor of conscience to the man who was the king's "living image" in an important outpost of the Monarchia Hispanica. ${ }^{63}$ Mendoça publication reminded both his penitent and the public of the principles of just government and of the crucial role of confessors as counsellors to achieve it.

Mendoça proceeded along a classical dialectical opposition of pro and contra arguments, to which he added a long conclusion that left no doubt about his judgement. The experts he quoted contradict the generally ventilated impression that Mendoça was just a mundane libertine. All the men who explicitly endorsed the Tratados were famous for their scholarly and moral rigor. There was the fellow Neapolitan Jesuit Martino Fornari (1547-1612), author of a rigorist confession manual, who had long taught at the Collegium Romanum. Another was the Theatine Giambattista del Tufo (d.1622), bishop of the small

6o This question has been ignored by intellectual historians; for the theological debate see Pasquale Porro, "Rien de personnel.' Notes sur la question de l'acceptio personarum dans la théologie scolastique," Revue des sciences philosophiques et théologiques 94 (2013): 481-509. For a thorough analysis of the debate see my monograph Voices of Conscience: Royal Confessors and Political Counsel in Seventeenth-Century Spain and France (Oxford: Oxford University Press, 2016), Ch. 7 .

61 Mendoça, Tres tratados, 12.

62 Ibid., 6.

63 For the notion of viceroys as "living images," see Alejandro Cañeque, The King's Living Image: The Culture and Politics of Viceregal Power in Colonial Mexico (New York: Routledge, 2004). 
town of Acerra near Naples, who in 1603 resigned the bishopric he had held since 1587 to dedicate the rest of his life to writing the history of his order. Mario de Andria (1537-1606) finally, was a Jesuit with recognized expertise in matters of confession and questions of restitution. ${ }^{64}$

The Tres tratados examine the question of acceptio along the classical lines of distributive justice and ownership of offices. They argued that just government was ruined because principles of favoritism supplanted criteria of qualification and suitability, severely damaging justice and the reputation of the Spanish monarch vis-à-vis his subjects in the viceroyalty. Mendoça blamed the viceregal councillors and local administrators for falsely labelling their sins and vices as virtuous liberality. Unlimited liberality, he noted, always tipped over into injustice. Moreover, viceroys as royal lieutenants did not enjoy the same degree of liberty as the monarch they represented; their authority was defined and limited by royal laws. ${ }^{65}$ Importantly, adopting a line of reasoning championed by the Dominican Domingo Bañez (1528-1604), who had argued that offices were bona communia over which the res publica still held ownership, Mendoça insisted that neither kings, nor viceroys, fully owned the offices they distributed. Limits on venality, however, followed not only from the question of ownership but also from the principle that just government must protect the subjects' right to receive competent and qualified officers, which venality and favoritism undermined. ${ }^{66}$ Mendoça stressed that Spanish legislation since the days of the Catholic Kings had always imposed severe limits on the sale of offices. ${ }^{67} \mathrm{He}$ also rejected the presumption that customary law permitted it, denouncing such arguments as a badly disguised excuse for misgovernment and abuse of office. Customary laws, so Mendoça, anticipating here

64 Mario de Andria participated at the fifth general congregation, where he was appointed together with Bellarmine and others to a commission to examine reserved cases, see Institutum Societatis Iesu, 2:268 (decr. 22). Andria and Fornari were Acquaviva's trusted informants in the province of Naples and Benevent, see ARSI, Neap. 6-II, f. $272^{2}$, Acquaviva to P. Martino Fornari (Benevento) and P. Maria d'Andria, November 11, 1600.

65 Mendoça, Tres tratados, 35.

66 Domingo Bañez, De iure et iustitia decisiones (Salamanca: Renaut fratres, 1584), quaest. LXIII, 279-84.

67 Mendoça, Tres tratados, 28. For restrictions on venality, see Francisco Tomás y Valiente, "Les ventes d'offices publics en Castille aux XVII ${ }^{\mathrm{e}}$ et XVIII ${ }^{\mathrm{e}}$ siècles," in Ämterkäuflichkeit: Aspekte sozialer Mobilität im europäischen Vergleich (17. und 18. Jahrhundert), ed. Klaus Malettke (Berlin: Colloquium Verlag, 1980), 89-114; for the continuing venality of offices in the kingdom of Naples, see Mireille Peytavin, "Naples, 1610: Comment peut-on être officier?," Annales: Histoire, sciences sociales 52, no. 2 (1997): 265-91. 
an argument Francisco Suárez (1548-1617) was to make in De legibus (1612), were null, unless they had been confirmed by royal ordinances. ${ }^{68}$

It is hardly surprising that Mendoça's robust legal and moral-theological denunciation of the commerce of offices and royal grace in the kingdom of Naples angered those who thrived on such practices, i.e. the local elites as well as the local clergy he accused of having failed in their duty of disciplining their consciences, as they should. If the ideas in the Tres tratados had indeed been the basis for his counsel to the viceroy, this might explain why the Neapolitan officers retaliated with damaging accusations about the confessor's moral corruption. The following (Jesuit) narrative that he was a loose cannon and morally dubious character, however, clearly jars with the support Mendoça had gathered from three clergymen famous for their impeccable conduct and doctrine. It points instead to deep divisions traversing the Neapolitan political and clerical elites and to the possibility that the accusations against Mendoça were partly a politically motivated fabrication to bring him down as soon as his powerful penitent drew his last breath. Yet, the timing of the publication of Tres tratados in 1602 also allows for a contrary interpretation. It is not beyond reasonable doubt to suggest that Mendoça used moral-theological arguments as a means of self-defence to discredit and delegitimize his critics. In any event, it is impossible to understand Mendoça's case without taking into account the Tres tratados, either as the source of, or response to his troubles, so far as they engaged the role of the princely confessor and his wider understanding of just and limited government which were relevant for his critique of his own order as well as for that of the government of Naples, capturing the inevitable frictions generated in counselling the conscience of rulers.

\section{Conclusion}

After his return to Spain, Mendoça was able to cultivate his open disobedience against Acquaviva not only because he initially enjoyed the support of the influential Lerma-faction, but also because of the special protection that Clement viII's breve had awarded him which suspended Acquaviva's order that Mendoça should return to Rome to be investigated. ${ }^{69}$ But matters soon changed. Clement viII's death in 1605 spared the order a doctrinal condemnation in

68 Mendoça, Tres tratados, 8, 29, 31; For Francisco Suárez's argument on the overriding authority of royal over customary laws see his Tractatus de legibus, ac Deo legislatore, in decem libros distributos (Mayence: Hermann Birckmann, 1619), lib. v, cap. XIII, 310.

69 See Visceglia, Roma papale, 198-201, with more detail on the surrounding court cabals. 
de auxiliis controversy and Acquaviva a humiliating trip to Spain, as Mendoça and his supporters had demanded. On both fronts Paul v (1552-1621) decided to take the heat out of the conflict and to protect the interests of the Society of Jesus as presented by its general, without antagonizing the Spanish crown. ${ }^{70}$ It was helpful in this context that by 1605 , Lerma and his sister no longer saw eye to eye, as the countess had taken exception to her brother's handling of court patronage. ${ }^{71}$ With his sister joining his critics, protecting Mendoça and entertaining his campaign against the general was probably no longer a priority for the royal favorite. This assisted a compromise that allowed all sides to save face. In 1607, Philip III nominated Mendoça to the bishopric of Cuzco in Peru, while Acquaviva agreed to his dismissal from the Society. ${ }^{72}$ With Mendoça removed, the upheaval amongst the Spanish Jesuits effectively collapsed. The extraordinary sixth general congregation in 1608 ended in a victory for the Jesuit general. The congregation unequivocally condemned the "troublemakers [...] who use the efforts of whatever persons, whether members of the Society or not to trouble the peace of the Society"73 and ratified the instructions for "confessors of royal persons" that Acquaviva had prepared. Moreover, the congregation underlined that it was "not licit for Ours-particularly by reason of their special status as dealing with princes or eminent personages or acting as their confessors - to accept anything for their own use and disposition, and that superiors should not have the authority to permit this." ${ }^{74}$

Meanwhile, as Mendoça sailed to Peru to end his days as a surprisingly wellreputed bishop and efficient administrator of his diocese,${ }^{75}$ his writings took on a life of their own. They entered the repertoire of texts quoted throughout the seventeenth century and in very different contexts when questions of counsel to princes were at issue. The Tres tratados lost some of their polemical contours and became a recommended work of sound advice for viceroys and

70 A Jesuit supplication to Paul v against Mendoça's breve denounces the Mendoça case and the de auxiliis controversy as elements of an anti-Jesuit plot, ARSI, Neap. Epist. 194-I,

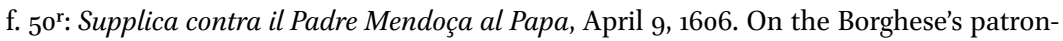
age interests in Spain, see Hillard von Thiessen, Diplomatie und Patronage: Die spanischrömischen Beziehungen in akteurszentrierter Perspektive, 1605-1621 (Epfendorf: Bibliotheca Academica, 2010).

71 See Thiessen, "Herrschen mit Verwandten und Klienten," 192.

72 The exact date of Mendoça's dismissal is not clear. Although ARsi, Hist. Soc. 54, f. $19^{\mathrm{r}}$ register him as being dismissed in 1604, neither the contemporary Jesuit correspondence nor Bernardo de Angelis's report from 1606 mention this fact at all.

73 Institutum Societatis Iesu, 2:289 (decr. 2).

74 Ibid., 2:297 (decr. 21).

75 Diccionario histórico de la Compañía de Jesús, 3:2624. 
their counsellors in matters of justice and liberality. ${ }^{76}$ The fate of Mendoça's criticism of the Jesuit Constitutions was entirely different. Although after 1608 the Society appeared pacified and the general's rule strengthened, some of the discontent moved underground, giving rise to a steady and corrosive trickle of "leaked" documents. The first were the famous Monita secreta in 1614, penned by a disgruntled Jesuit; Mendoça's French Advis followed in 1615, the year of Acquaviva's death. The likeliest explanation is that a Jesuit malcontent in Rome or Madrid orchestrated the publication of Mendoça's manuscript, which must have widely circulated in Spanish before the sixth general congregation, but of which no copy nowadays exists in the Jesuit central archives. The Advis and the Monita throw into sharp relief what Sabina Pavone has called "Jesuit antiJesuitism." 77 They were remembered together and were still a staple tool of polemics in the campaign against Eberhard Nithard (1607-81), the Jesuit confessor of Queen Mariana de Austria (1634-96), to suggest that he was not to be trusted with counselling the queen on matters of state, as he might leak them to Rome. ${ }^{78}$

Over the seventeenth century, Mendoça's Advis, the Monita, and Mariana's critique became a topical trilogy within the ever-widening corpus of anti-Jesuit writing, despite some substantial differences between the three texts. While the Monita adopted the satirical device of posing as an "authentic" Jesuit regulation that supported theories of a concerted Jesuit conspiracy "via the confessional," Mariana's and Mendoça's writings were leaked testimonies, revealing deep constitutional tensions amongst the Jesuits far beyond the regulations of the Society of Jesus itself. Both Spaniards deplored the order's growing centralization and opposed in no uncertain terms the unbalanced and absolute power of the general. Mobilizing a classical argument in political theory, they identified the suppression of good counsel as a major cause and attribute of tyranny. What distinguished Mendoça's criticism from Mariana's was the urgency with which he insisted on the necessity of confession as a means of good and fraternal counsel, denouncing its distortion in the name of discipline and

76 Pedro de Avilés, Advertencias de un Politico a su Principe (Naples: Novelo de Bonis 1673), discurso 9 and 10, 49-132; Mendoça was also positively mentioned in the widely circulating Summa by the laxist Theatine Antonino Diana, Summa Diana (Lyon: Laurent Arnison, 1652), 723-25. Long excerpts from the Tratados also in Francisco Esteban, Cathedra de Liberalidad que el confessor lee y el penitente oye (Madrid: Juan García Infançon, 1710), Ch. 49 .

77 Sabina Pavone, "Antijésuitisme politique," 139-64.

78 Biblioteca Nacional de España, ms. 8344 , ff. $234^{\mathrm{r}}-245^{\mathrm{v}}$ : "Dudas politicas." On the conflict between Don Juan José and Nithard, see Hélö̈se Hermant, Guerres de plumes: Publicité et cultures politiques dans l'Espagne du XVII ${ }^{e}$ siècle (Madrid: Casa de Velázquez, 2012). 
obedience. ${ }^{79}$ This was certainly drawn from his own experience as a victim of Jesuit regulations, but also as a protagonist of good counsel, as he saw it, in his role as princely confessor. The two sides were not randomly connected by experience alone; they seem to have been informed by an underlying understanding according to which confession was primarily good counsel to establish good and just government, within the Society of Jesus, and, through its princely confessors, also in the saeculum.

79 The regime of supervision and slanderous gossip within the Society is a topic in the Monita secreta, see Sabina Pavone, The Wily Jesuits and the Monita Secreta: The Forged Secret Instructions of the Jesuits: A History and a Translation (St. Louis, Mo: Institute for Jesuit Sources, 2005), 229-30. 